\title{
Trans Ideology and the New Ptolemaism in the Academy
}

\author{
Kathleen Lowrey ${ }^{1}$
}

Published online: 3 March 2021

(c) The Author(s), under exclusive licence to Springer Science+Business Media, LLC part of Springer Nature 2021

In March 2020, I was dismissed by the then-Dean of Arts, Lesley Cormack, from my position as undergraduate programs chair in the Department of Anthropology at the University of Alberta in response to student objections to my gender critical feminist views. In June 2020, a colleague in English and Film Studies wrote up an account of my case as a post for the blog maintained by the Center for Free Expression at Ryerson University (Sale, 2020). This post attracted broad media attention (Kay, 2020, among many others), and I became one among the world's growing number of academic feminist women "canceled" for her gender critical views (FiLiA, 2020; Lowrey, 2020a).

To go beyond the particulars of my case and articulate a more general disquiet, I will start with what was most personally distressing about this experience. Almost all of my most enthusiastic public attackers were feminist academic women. Male administrators played important roles behind the scenes, and I do not even know the identities of most students involved in calling for my firing (interestingly, two students-both gay men from immigrant backgrounds-independently contacted me in the aftermath to describe the intense pressure that fellow students brought to bear on them to denounce me). However, I do know that the people who took to Twitter, to Facebook, and to an internal web discussion forum for University of Alberta faculty to charge me with being a dangerous threat in their midst were in their overwhelming majority feminist academic women, many of whom I had known and been friendly with for years. One feminist academic woman whom I did not know at all took to an anthropology blog for which I was once a founding contributor to fulsomely express the absolute thoroughness of her disdain for me in two separate blog posts (Shulist, 2020a, b). In an irony not lost on me, I had left this very blog some 15 years prior after a ferocious controversy in which I was asked (and refused) to apologize for my mordant reaction to the

Kathleen Lowrey

klowrey@ualberta.ca

1 Department of Anthropology, University of Alberta, Edmonton, AB T6G 2H4, Canada musings of a male contributor about the ways certain feminists failed to appreciate the subtle cultural charms of female genital mutilation (Wax, 2006).

Of course, misogynists have a ready explanation for the phenomenon I experienced: colloquially put, "cattiness" or the supposed tendency of women to attack other women with unique remorselessness. On both feminist and empirical grounds, I don't think this is right. To begin with, my staunchest defender (with respect to academic freedom) was a female colleague, a woman scholar of whom I will have more to say anon. The weightier counter-argument to the misogynist take has to do with a broadly disturbing turn in the social sciences and humanities that began in the late twentieth century and that has been accelerating rapidly in the twenty-first.

\section{The New Ptolemaism}

Gabriel Rockhill (2020) opens his essay "The Radical Recuperator" with a wonderful analogy:

Ptolemy constructed an inordinately complex model of the universe in order to make all of the empirical data conform to a central, organizing false assumption, namely, that the earth was at the center. Michel Foucault, as we shall see, made a similar contribution to contemporary social science.

As Rockhill has it, Foucault is the exemplary case of the "intellectual who appears radical in certain circles but whose primary social function is to recuperate truly radical critique within the extant system, thereby policing the left border of critique" (ibid). Rockhill's argument (with which I sympathize) is concerned with the defanging of Marxist analysis in the social sciences. But the saturating influence of "Ptolemaic" modes of analysis influenced by Foucault has had an equivalently corrosive effect on traditional and conservative modes of scholarly inquiry. "Saturating" is no exaggeration: Foucault is the most-cited scholar in the humanities ("Most cited", 2009). His influence in the social sciences varies by discipline: minor in Economics, enormous in Sociology, but still the only author 
with two books in the top 10 among most-cited books across the social sciences (Green, 2016).

Foucault's influence in the academy is at least as often lamented as celebrated, and I will not attempt in what follows a comprehensive critique of his work. Instead, I will focus on one tendency his example has encouraged, which, using Rockhill's analogy, I will call the "new Ptolemaism." This is a push for scholarship to be insistently insular and to be much less interested in the study of the world than in the study of the study of the world. This kind of work, which is by now very common in the social sciences and humanities, performs the same neat trick every time. It turns out, in every such analysis, that the framing of inquiry turns out to be more significant than the object of inquiry. Inevitably, the most important research site thus becomes academia itself because academia is where the framing happens. Any real understanding of the world-and any disruption of it-must on this view begin within the academy. The academy becomes the center around which everything else revolves, and the most profound forms of intervention into systems of "power/ knowledge," to use Foucault's famous phrase, are those that upend academic conventions.

The upending part is important. Although Foucault is usually described as a "post-structuralist," a structuralist fascination with binary oppositions animates the scholarly tradition he initiated. Both "boundaries" and "transgression" are recurrent themes in this body of work: boundaries being bad and transgression good. The general formula, however, is always the same: if for a structuralist oppositions are constitutive-think of Lévi-Strauss (1983 [1964]) on the "the raw versus the cooked" and other such binaries as generative cultural operators-Foucauldian post-structuralists are interested in binaries that either are or can be understood to be hierarchical. The key liberatory project is to discern how these are ordinarily arrayed and then to reverse them. It's structuralist music, but played backwards in order to unleash supposedly subversive messages embedded therein.

This is not to say the trick never works. Foucault is a lot of fun to teach. Discipline and Punish (1977 [1975]), for instance, begins with a gruesome scene of Enlightenment era torture. The text argues that these kinds of grotesque displays of punitive power belied the weakness of the government administering them. At the other end of the modern era-our own-there are no public gibbets nor town square lashings with cats of nine tails. Instead, the scariest thing that can happen to you is that quiet serious men in dark suits ask you to come along with them. If things don't go well, you may end up quite privately alone in a cell for $23 \mathrm{~h}$ a day (or, outside the West, in a "black site" no one admits exists). Today, governments don't have to make a noisy, bloody show of their power. They have so much that they find it convenient to be rather understated about it all. Ordinarily, we think of that poor eighteenth century tortured sap as unfree and his government as tyrannical, compared to our late modern liberated selves with our constitutional democracies. Foucault says: look again.

Having seen Foucault stick this landing, many scholars have also had a go. To take a thing, turn it topsy-turvy, and declare eh voila! has become a kind of patented double-action machine in scholarly work. I don't want to be unkind to anyone in particular, so I won't name the book, but a friend recently sent me the blurb for a new publication in anthropology from a highly prestigious academic press. It turns out that a thing most people think of as "traditional" is actually "modern" and-get this-instead of being located in the West that thing happens in the non-West, such that modernity is a non-Western invention conjured up by exactly the reverse sort of people than most (Western academic) people would suppose. The author says, in effect: look again.

The problem with this analysis is the same as in Foucault's analysis, above. If you flip certain operators and ignore lots of context, it is possible to produce provocative surprises. But even given supermax prisons-which are indeed horrible-the lack of public torture seems like an improvement, and you'd probably want to pay attention not just to binomial terms amenable to inversion (discipline vs. liberty) but shaggier phenomena like judicial processes in assessing the general state of human affairs in one or another era. Finally, late modern governments continue to have a line in noisy, bloody shows of power. They just put them on outside of the West. Ask the people of Vietnam, Afghanistan, Iraq, or Yemen.

It is one of the great ironies of this kind of work that it supposes itself to be radically transgressive on the subject of epistemology and yet is rigidly formulaic in application. It will identify two terms, one privileged, the other not; the analysis "violates" the boundaries of this order by turning it upside down. It can be good fun, but part of the fun is the safety of it: it preserves the overall order very perfectly, which is why it is so attractive to elites.

Consider present day calls to remake the academy. There should be more soft sociology of the hard sciences; there should be more women in male dominated disciplines; we should "indigenize" the university. There are two terms in each case; we should reverse the conventional hierarchy of those terms; and the results will be profoundly liberatory, because, Ptolemaically, the university rather than the world is the most important locus of struggle. I have written about the ways that recent scholarship of this sort has attempted to pay a kind of compliment to Amerindian shamanism by, first, placing it in binary relation to scientific practice (either biomedicine or ecological managerial technique) and then asserting that actually shamanism is the superior term in the relation. This evacuates shamanism of its originality and uniqueness as a phenomenon culturally independent of the scientific tradition. Worse, it charges shamanism with solving all sorts of ills Amerindian societies had nothing to do with creating (Lowrey, 2020b). The putative inversion in fact 
pays extravagant homage to Western science (by figuring shamanism as a variant of it) and then, in high Ptolemaic style, locates the motor of social change (in public health or ecosystemic flourishing) on the conceptual rather than the material plane.

\section{Sex, Ptolemaic Style}

The pervasiveness of this formula helps to explain the widespread enthusiasm for gender identity ideology in the academy. The relevant flippages are of at least three kinds. First is the reversal of the sex:gender relation as it is commonly understood. Ordinarily sex has primacy. It is the biological given upon which the cultural constructions of gender are elaborated. In gender identity ideology, the terms are reversed. Gender is essential, and sex is the unsteady social construct. Second is the relation of men to women. Conventionally, the social standing of men is understood to be privileged relative to that of women. This relationship is reversed in gender identity ideology. Trans identified men ("transwomen") are figured as vulnerable relative to women and are even described as the most vulnerable of all women. Third, the quotidian apprehension is that children develop their gender identities as they grow up and engage with and adjust to cultural norms. Under gender identity ideology, it is asserted that children know from very young ages exactly their gender identities independent of cultural conditioning. As a corollary, adult men who express gender identities late in life that appear to be wholly fashioned out of sexist cultural norms about femininity have in fact been real women-the very realest of women-all along. The department colleague who was my most enthusiastic denouncer placed two signs on her office door after I put up gender critical feminist messaging on mine: "trans rights are human rights" and "transwomen are women." She understood very well the messaging required of a "trans ally" and displayed it quite correctly.

Gender critical feminists like me notice, of course, that one infinitely more often sees and hears the slogan "transwomen are women" than its counterpart "transmen are men." To understand why this is the case, you'd have to pay attention to patterns of power in the world rather than to Ptolemaic valence-flipping. One of the signs on my office door that most infuriated feminist academic women colleagues on social media described the parallels between men's rights activism and trans rights activism. Many feminist academic women clearly saw it as their moral and intellectual duty to decry this assertion.

Why? I think the answer is, again, threefold. First, the pervasiveness of Foucauldian modes of analysis in the academy makes the form of argumentation in gender identity ideology immediately persuasive to many academics in the social sciences and humanities. Second, many feminist academics who are women understand their own experience as exactly an "upending" along Foucauldian lines: where once the academy was a male space, they are making it a female one. Third, the Ptolemaic framing that places the academy at the center of political struggle is replicated within the university itself, such that the traditional "softer" disciplines of the social sciences and humanities become the "stronger" pole in this struggle. The soft part of the university is to lead the hard part, and this will end in transforming the world. Embedded within this is the responsibility of feminist women academics in the social sciences and humanities to "do the work," as it were, of this world-turning. Gender identity ideology in the setting of the university, then, appears as a sort of nested microcosm of everything: defending vulnerable trans identified men against perceived threats becomes a world-historical responsibility. And, peering through the same ideological microscope, nothing looms larger as a threat than a feminist academic woman, in the social sciences and humanities, who says that transwomen are not tender seedlings of change who, once sufficiently nurtured, will turn the world's injustices all topsy-turvy but that they are entitled men with regressive notions about femininity and that refusing to indulge them is a necessary undertaking.

\section{The New Ptolemaism and the Traditional University}

My staunchest defender during my "cancelation" was a woman academic in the humanities who does not share my stance on trans issues but approached my case as a straightforward one of academic freedom. She is a Shakespeare scholar, past president of our faculty association, and consistent advocate for collegial governance within the university. At the University of Alberta as at many universities and colleges, this collegial governance is under siege by administrators who would like to replace it with something more closely approximating corporate management and who view dissident scholars as brand risks (Ginsberg, 2011; Newfield, 2018; Readings, 1997). While this colleague's politics (like those of the majority of university professors) are left-leaning, her commitment to the university is grounded in tradition. I don't think this is incidental to the role she played in my case.

The new Ptolemaism is remarkably amenable to this emergent approach to university governance. At first blush, this would seem an unlikely alignment. Scholars influenced by Foucault usually figure themselves as political revolutionaries, while administrators looking to remake the university are unabashedly influenced by capitalist models (Christensen \& Eyring, 2011). Where their interests intersect is in their shared contempt for the traditional university and their shared sense that nothing is more vital than deconstructing and reconstructing it along novel lines. This, I believe, has created the strange alliance one sees in so many universities 
where administrators take up the banner of "equity, diversity, and inclusivity" (EDI) initiatives and putatively revolutionary faculty increasingly enter the administrative ranks. From an administrative point of view, EDI creates unprecedented entrée into processes once, frustratingly, entirely in the hands of faculty: hiring, promoting, and honoring. From a revolutionary faculty point of view, a berth in administration is no longer a cross to be borne for some portion of an academic career but instead the best means to do the most important possible work because it affords an opportunity to transform the social construction of knowledge, which they take to be key to remaking the world.

To be, in any way, a traditional scholar under such circumstances is to be a problem. Radical feminists are "traditionalists" in this sense, in that they root their analysis in the materiality of biological sex and take the oppression of women to be linked to the control of reproduction. In the present scholarly ecumene, this aligns them in some respects with scholars who are traditional and conservative, and explains why they, like conservatives, are so often in trouble with their institutions under present conditions.

There are few grounds for optimism about the likelihood of collaboration. In my case, I have simultaneously increased my involvement with radical feminist organizations (like the Women's Human Rights Campaign) and fora (like Spinster. $\mathrm{xyz}$ ) while also joining those groups that do come to the defense of embattled scholars and which tend to be rightward-leaning (Society for Academic Freedom and Scholarship, Heterodox Academy-Canada). I cannot say I see much common ground across them, though there are people I like very much in all of the settings. There is nothing like the coincidence of predilection and access to institutional power observable in the new Ptolemaist/woke administrator alliance. My own sense is that any real change in this situation will come from a direction that this alliance treats as peripheral: that is, not from the academy but from the world. I wonder if it will take a form that any of us-radical, traditionalist, new Ptolemaist, or other-will welcome.

\section{References}

Christensen, C., \& Eyring, H. J. (2011). The innovative university: Changing the DNA of higher education from the inside out. San Francisco, CA: Jossey-Bass.

FiLiA. (2020, July 25). Eleven women in academia censored or threatened because of their views on sex, gender, or queer theory [Blog post]. Retrieved from https://filia.org.uk/news/2020/7/5/10-women -in-academia-censored-or-threatened/
Foucault, M. (1977). Discipline and punish. (A. Sheridan, Trans.). New York, NY: Pantheon. (Original work published 1975)

Ginsberg, B. (2011). The fall of the faculty: The rise of the all-administrative university and why it matters. Oxford, England: Oxford University Press.

Green, E. (2016, May 12). What are the most-cited publications in the social sciences (according to Google scholar)? [Blog post]. Retrieved from https://blogs.lse.ac.uk/impactofsocialscienc es/2016/05/12/what-are-the-most-cited-publications-in-the-socia 1-sciences-according-to-google-scholar/

Kay, B. (2020, June 9). U of A professor holds the line on free expression. The National Post. Retrieved from https://nationalpost.com/ opinion/barbara-kay-u-of-a-professor-holds-the-line-on-free-expre ssion/

Lévi-Strauss, C. (1983). The raw and the cooked: Mythologiques (Vol. One). (J. \& D. Weightman, Trans). Chicago: University of Chicago Press. (Original work published 1964)

Lowrey, K. (2020a, June 12). From South American anthropology to gender-crit cancel culture: My strange feminist journey. Quillette. Retrieved from https://quillette.com/2020/06/12/from-south-ameri can-anthropology-to-gender-crit-cancel-culture-my-strange-femin ist-journey/

Lowrey, K. (2020b). Shamanism and vulnerability on the North and South American Great Plains. Louisville, CO: University Press of Colorado.

Most cited. (2009, March 26). Most cited authors of book in the humanities, 2007. Times Higher Education. Retrieved from https://www. timeshighereducation.com/news/most-cited-authors-of-books-inthe-humanities-2007/405956. article?storyCode $=405956 \&$ secti oncode $=26 \mathrm{~W} /$

Newfield, C. (2018). The great mistake: How we wrecked public universities and how we can fix them. Baltimore, MD: Johns Hopkins University Press.

Readings, B. (1997). The university in ruins. Cambridge, MA: Harvard University Press.

Rockhill, G. (2020, October 12). Foucault: The faux radical. The Philosophical Salon: A Los Angeles Review of Books Channel. Retrieved from https://thephilosophicalsalon.com/foucault-the-faux-radical/

Sale, C. (2020, June 2). Academic freedom and perceptions of harm [Blog post]. Retrieved from https://cfe.ryerson.ca/blog/2020/06/ academic-freedom-and-perceptions-harm/

Shulist, S. (2020a, June 18). Academic labour and academic freedom: What does it mean to be "fired"? Anthrodendum. Retrieved from https://anthrodendum.org/2020/06/18/academic-labour-and-acade mic-freedom-what-does-it-mean-to-be-fired/

Shulist, S. (2020b, June 22). Like talking to a door: Thoughts on the interactional and semiotic dynamics of an office door. Anthrodendum. Retrieved from https://anthrodendum.org/2020/06/22/ like-talking-to-a-door-thoughts-on-the-interactional-and-semio tic-dynamics-of-an-office-door/

Wax, D. (2006, June 6). Female genital cutting, sexuality, and antiFGC advocacy. Savage Minds: Notes and Queries in Anthropology. Retrieved from https://savageminds.org/2006/06/06/female-genit al-cutting-sexuality-and-anti-fgc-advocacy/

Publisher's Note Springer Nature remains neutral with regard to jurisdictional claims in published maps and institutional affiliations. 